\title{
PENGARUH BEBAN, DISIPLIN DAN LINGKUNGAN KERJA (STUDI PADA UMKM PENGRAJIN SEPATU DI WILAYAH GUNUNG PUNTANG)
}

\section{Influence of Burden, Discipline, Work Environment (Study on MSMEs of Shoes Craftsmen in the Gunung Puntang Region)}

\author{
Palupi Permata Rahmi ${ }^{1}$, Eneng Riskayani ${ }^{2}$ \\ 1,2Universitas Indonesia Membangun (INABA) \\ Email:palupi.permata@inaba.ac.id1, riskayani2@gmail.com ${ }^{2}$
}

\begin{abstract}
ABSTRAK
Penelitian ini bertujuan untuk menganalisis pengaruh beban kerja, disiplin kerja dan lingkungan kerja terhadap produktivitas kerja Karyawan (Studi Pada UMKM Pengrajin Sepatu Di Wilayah Gunung Puntang). Metode yang digunakan dalam penelitian ini adalah metode kuantitatif dengan pendekatan deskriptif dan verifikatif. Teknik pengumpulan data dilakukan dengan metode simple random sampling dengan menggunakan rumus Slovin berjumlah 51 orang responden. Metode analisis data untuk menjawab rumusan masalah menggunakan analisis deskriptif, uji asumsi klasik, uji regresi berganda, uji koefisien korelasi, uji korelasi berganda, uji koefisien determinasi, serta pengujian hipotesis dengan uji t dan uji F. Hasil penelitian ini dapat disimpulkan bahwa secara parsial, beban kerja berpengaruh terhadap produktivitas kerja Karyawan (Studi Pada UMKM Pengrajin Sepatu Di Wilayah Gunung Puntang). Secara parsial, disiplin kerja tidak berpengaruh terhadap produktivitas kerja Karyawan (Studi Pada UMKM Pengrajin Sepatu Di Wilayah Gunung Puntang). Secara parsial, lingkungan kerja berpengaruh terhadap produktivitas kerja Karyawan (Studi Pada UMKM Pengrajin Sepatu Di Wilayah Gunung Puntang). Secara simultan, beban kerja, disiplin kerja dan lingkungan kerja berpengaruh terhadap produktivitas kerja Karyawan (Studi Pada UMKM Pengrajin Sepatu Di Wilayah Gunung Puntang).
\end{abstract}

Kata Kunci: Beban, Disiplin, Lingkungan, Produktivitas Kerja

\section{ABSTRACT}

This study aims to analyze the effect of workload, work discipline and work environment on work productivity (Study on MSME Shoe Craftsmen in the Gunung Puntang Region). The method used in this study is a quantitative method with a descriptive and verification approach. The data collection technique was carried out by simple random sampling method using the Slovin formula to collect 51 respondents. data analysis method to answer the problem formulation using descriptive, classical assumption test, multiple regression test, correlation coefficient test, multiple correlation test, analysis of the coefficient of 
determination, as well as hypothesis testing with $t$ test and F test. Partially, work discipline has no effect on employee work productivity. Partially, the work environment affects employee work productivity (Study on shoe craft SME in Gunung Puntang area). Simultaneously, work discipline and work environment have an effect on on employee work productivity (Study on MSMEs of shoe craftsmen in the Gunung Puntang area).

Keywords: Burden, Discipline, Environment, Work Productivity

\section{PENDAHULUAN}

Persaingan yang semakin ketat dalam dunia usaha ini merupakan cambuk bagi perusahaan untuk dapat mencari strategi yang tepat dalam mempertahankan kehidupan perusahaan. Salah satu usaha yang dilakukan perusahaan yaitu dengan mengelola dan menggunakan sumber daya manusia dengan baik dan benar. Sumber daya manusia merupakan bagian yang cukup penting dalam pencapaian tujuan organisasi baik itu perusahaan besar maupun kecil. Organisasi apapun bentuknya pasti membutuhkan manajemen yang mampu mengkoordinir setiap perubahan yang terjadi. Untuk itu pengelolaan SDM dalam sebuah perusahaan menjadi sangat penting sehingga harus mendapat prioritas utama, jika perusahaan itu ingin maju, juga menghasilkan produk dan jasa yang dapat dipasarkan dan mencapai tujuan sesuai yang diharapkan, sumber daya yang terdiri dari modal, manusia, dan mesin.

Menurut Mangkunegara (2017), manajemen sumber daya manusia merupakan suatu perencanaan, pengorganisasian, pelaksanaan, dan pengawasan terhadap pengadaan, pengembangan, pemberian balas jasa, pengintegrasian, pemeliharaan, dan pemisahan tenaga kerja dalam rangka mencapai tujuan organisasi. Tingginya angka produktivitas kerja merupakan impian setiap perusahaan karena dengan tingginya produktivitas kerja karyawan akan berdampak pada peningkatan dan pendapatan perusahaan yang merupakan tujuan dan cita-cita perusahaan. Dengan adanya produktivitas kerja, diharapkan pekerjaan akan terlaksana secara efektif dan efisien sehingga sangat diperlukan dalam pencapaian tujuan yang sudah ditetapkan.

Salah satu faktor untuk meningkatkan produktivitas kerja karyawan yaitu dengan memperhatikan beban kerja. Menurut Munandar (2011), beban kerja adalah suatu tugas yang diberikan kepada karyawan untuk diselesaikan dengan menggunakan keterampilan dan potensi dari karyawan dan pada waktu tertentu. Faktor lain yang memengaruhi produktivitas kerja adalah disiplin kerja. Menurut Susanto (2016), disiplin kerja merupakan tindakan pimpinan untuk memotivasi para bawahannya agar dapat memenuhi berbagai ketentuan dan peraturan yang berlaku dalam suatu perusahaan, yang di dalamnya mencakup adanya kepatuhan karyawan terhadap tata tertib atau ketentuan-ketentuan, serta adanya sanksi hukuman bagi yang melanggar. Suatu pelanggaran yang dilakukan karyawan harus ada tindakan tegas serta tidak membiarkan pelanggaran tersebut berlarut- 
larut. Faktor penting yang berpengaruh terhadap produktivitas kerja adalah lingkungan kerja. Menurut Desmonanda (2016), lingkungan kerja adalah suatu situasi dan kondisi yang ada dalam lingkungan kerja itu sendiri seperti bagaimana perlakuan dari atasan dan rekan kerja, beban kerja, penghargaan bagi karyawan yang berprestasi dan lain sebagainya. Berikut ini data target dan hasil produksi di UMKM sepatu di Wilayah Gunung Puntang pada tahun 2020 yang dapat dilihat pada Tabel 1 :

Tabel 1. Data Produktivitas dan Pencapaian Kerja Karyawan

\begin{tabular}{lcccccc}
\hline \multicolumn{1}{c}{ Bulan } & Tahun & $\begin{array}{c}\text { Tenaga } \\
\text { kerja }\end{array}$ & $\begin{array}{c}\text { Target } \\
\text { perbulan } \\
\text { (Pasang) }\end{array}$ & $\begin{array}{c}\text { Hasil } \\
\text { produksi } \\
\text { Perbulan } \\
\text { (Pasang) }\end{array}$ & Produktivitas & $\begin{array}{c}\text { Pencapaian } \\
\text { (\%) }\end{array}$ \\
\hline Januari & 2020 & 102 & 2.230 & 1.900 & 18,627 & 85 \\
Februari & 2020 & 102 & 2.230 & 1.870 & 18,333 & 83 \\
Maret & 2020 & 102 & 2.230 & 1.875 & 18,382 & 84 \\
April & 2020 & 102 & 2.230 & 1.700 & 16.666 & 76 \\
Mei & 2020 & 102 & 2.250 & 1.850 & 18,137 & 82 \\
Juni & 2020 & 102 & 2.235 & 1.700 & 16.666 & 76 \\
Juli & 2020 & 102 & 2.240 & 2.000 & 19,607 & 89 \\
Agustus & 2020 & 102 & 2.230 & 1.950 & 19,117 & 87 \\
September & 2020 & 102 & 2.230 & 1.832 & 17,960 & 82 \\
Oktober & 2020 & 102 & 2.225 & 2.000 & 19.607 & 89 \\
November & 2020 & 102 & 2.230 & 1.800 & 17,647 & 80 \\
Desember & 2020 & 102 & 2.250 & 1.950 & 19,117 & 86 \\
\hline Jumlah & & & $\mathbf{2 6 . 8 1 0}$ & $\mathbf{2 2 . 4 2 7}$ & $\mathbf{5 3 . 1 0 5 , 9 3}$ & $\mathbf{8 3}$ \\
\hline Rata-rata & & & $\mathbf{2 . 2 3 4 , 1 6 7}$ & $\mathbf{1 . 8 6 8 , 9 1 7}$ & $\mathbf{4 . 4 2 5 , 4 9 4}$ & $\mathbf{8 3}$ \\
\hline
\end{tabular}

Sumber : Data Internal UMKM Sepatu Wilayah Gunung Puntang (2020)

Berdasarkan data pada Tabel 1, menunjukkan bahwa realisasi pencapaian target karyawan masih fluktuatif hal tersebut dilihat dari pencapaian target pada tahun 2020 dengan rata-rata pencapaian target 83 persen sementara target yang telah ditentukan perusahaan 95 persen, data produktivitas tertinggi pada bulan Desember 19,117 dan terendah pada bulan Juni 16,666 dengan jam kerja selama 8 jam per hari, produktivitas kerja karyawan mengalami turun naik dari setiap bulannya. Hal ini mengindikasikan bahwa produktivitas kerja karyawan UMKM Pengrajin Sepatu di Wilayah Gunung Puntang masih belum maksimal.

Hasil observasi penelitian di dukung wawancara dengan kepala bagian UMKM pembuatan sepatu di Wilayah Gunung Puntang dan beberapa pegawai lainnya ada yang memengaruhi produktivitas kerja karyawan itu sendiri salah satunya faktor beban kerja. Beban kerja yang diberikan sejalan dengan target produksi yang cenderung bertambah setiap bulannya, sehingga karyawan memerlukan waktu tambahan untuk dapat menyelesaikan target produksi.

Selain faktor lingkungan kerja, faktor lain yang dapat memengaruhi kinerja karyawan adalah faktor disiplin kerja, tuntutan pekerjaan yang menjadi tanggung jawab karyawan membutuhkan disiplin kerja yang optimal agar 
pekerjaan tersebut bisa sesuai dengan yang diharapkan perusahaan. Disiplin kerja sebaiknya harus ditanamkan dalam diri setiap pegawai, bukan karena paksaan atau karena tuntutan semata akan tetapi didasarkan atas kesadaran dalam diri setiap pegawai. Untuk mendapatkan disiplin kerja yang baik, pegawai harus taat terhadap aturan waktu, taat terhadap peraturan perusahaan, taat terhadap aturan perilaku dalam bekerja dan taat terhadap aturan lainnya yang telah ditetapkan oleh perusahaan. Berdasarkan hasil observasi yang diperoleh dari pemilik UMKM pengrajin sepatu di Wilayah Gunung Puntang telah didapatkan data absensi karyawan yang dapat terlihat pada Tabel 2 :

Tabel 2. Data Absensi Karyawan

\begin{tabular}{lccccc}
\hline \multirow{2}{*}{ Bulan } & \multirow{2}{*}{ Tahun } & \multicolumn{5}{c}{ Jumlah Pegawai yang Tidak Hadir dan Terlambat } \\
\cline { 2 - 6 } & & Izin & Sakit & Tanpa Keterangan & Terlambat \\
\hline Januari & 2020 & 3 & 3 & 4 & 5 \\
Februari & 2020 & 1 & 2 & - & 9 \\
Maret & 2020 & 2 & 3 & - & 7 \\
April & 2020 & 2 & - & 5 & 6 \\
Mei & 2020 & 1 & 3 & 4 & 7 \\
Juni & 2020 & 1 & 4 & 3 & 8 \\
Juli & 2020 & 1 & - & - & 6 \\
Agustus & 2020 & 2 & 3 & 4 & 8 \\
September & 2020 & 3 & 2 & 5 & 4 \\
Oktober & 2020 & 4 & - & 3 & 8 \\
November & 2020 & 3 & 1 & 4 & 8 \\
Desember & 2020 & 3 & 1 & 3 & $\mathbf{8 1}$ \\
\hline JUMLAH & & $\mathbf{2 6}$ & $\mathbf{2 2}$ & $\mathbf{3 5}$ & 8 \\
\hline
\end{tabular}

Sumber : Data Internal UMKM Sepatu Wilayah Gunung Puntang (2020)

Berdasarkan survei yang dilakukan dapat dilihat Tabel 2, bahwa disiplin kerja karyawan pada UMKM sepatu di Wilayah Gunung Puntang belum maksimal terutama dalam hal kehadiran, dan tanggung jawab. Batas waktu masuk kerja adalah 08.00 WIB dan batas pulang adalah 17.00 WIB dengan total jam kerja adalah 8 jam, dalam kenyataannya banyak karyawan yang datang terlambat. Hal ini terbukti dengan adanya data absensi pegawai terdapat keterlambatan tertinggi pada periode tahun 2020 yaitu total sebanyak 81 orang pegawai yang terlambat. Kesimpulannya masih banyak karyawan yang kurang memperhatikan ketepatan waktu dalam bekerja dan kurang disiplin waktu sehingga berpengaruh terhadap produktivitas kerja. Disiplin sebaiknya harus ditanamkan dalam diri setiap pegawai, bukan karena paksaan atau karena tuntutan semata akan tetapi kesadaran dalam diri setiap pegawai. Untuk mendapatkan disiplin kerja yang baik pegawai harus taat terhadap aturan waktu. Taat terhadap peraturan perusahaan, taat terhadap aturan perilaku dalam bekerja dan taat terhadap aturan lainnya yang telah ditetapkan oleh perusahaan.

Selain itu, hasil observasi penelitian di dukung wawancara dengan kepala bagian UMKM pembuatan sepatu di Wilayah Gunung Puntang dan beberapa pegawai lainya, faktor lainnya yang memengaruhi produktivitas kerja karyawan 
adalah faktor lingkungan kerja. Terkait dengan lingkungan kerja peneliti mendapatkan informasi dengan melakukan wawancara dengan pegawai UMKM pengrajin sepatu di Wilayah Gunung Puntang bahwa fasilitas yang disediakan cukup memadai akan tetapi ada yang perlu diperbaiki atau ditambah. Pegawai mengeluhkan fasilitas yang kurang baik di lingkungan kerja diantaranya ruangan kerja yang sempit dan berdesakan dengan barang produksi, sirkulasi udara tidak stabil sehingga udara dalam ruangan kerja menjadi pengap dan menyebabkan suhu ruangan kerja menjadi panas, tidak disediakan tempat menyimpan makanan untuk pegawai sehingga makan tercampur dengan bahan baku yang akan diproduksi. Fasilitas yang kurang ini akan memperlambat kinerja karyawan dan sangat memengaruhi produktivitas kerja karyawan. Berdasarkan hasil pra survei yang mengenai Lingkungan kerja di UMKM pengrajin sepatu di Wilayah Gunung Puntang dapat dilihat pada Tabel 3 berikut ini :

Tabel 3. Hasil Kuisioner Pra Survei Lingkungan Kerja

\begin{tabular}{|c|c|c|c|c|c|c|c|}
\hline \multirow{2}{*}{ No } & \multirow{2}{*}{ Lingkungan Kerja } & SS & $S$ & KS & TS & STS & \multirow{2}{*}{ SKOR } \\
\hline & & 5 & 4 & 3 & 2 & 1 & \\
\hline 1 & $\begin{array}{l}\text { Penerangan yang ada (sinar matahari } \\
\text { dan listrik) di ruang kerja telah sesuai } \\
\text { dengan kebutuhan }\end{array}$ & 1 & 4 & 11 & 3 & 1 & 61 \\
\hline 2 & $\begin{array}{l}\text { Kondisi udara di ruang kerja } \\
\text { memberikan kenyamanan pada saya } \\
\text { selama bekerja }\end{array}$ & 2 & 1 & 10 & 5 & 2 & 56 \\
\hline 3 & $\begin{array}{l}\text { Peralatan yang disediakan sesuai } \\
\text { pekerjaan saya }\end{array}$ & 3 & 2 & 9 & 4 & 2 & 60 \\
\hline 4 & $\begin{array}{l}\text { Peralatan kerja yang saya gunakan } \\
\text { aman dari kecelakaan (cutting) }\end{array}$ & 2 & 3 & 9 & 5 & 1 & 60 \\
\hline 5 & $\begin{array}{l}\text { Fasilitas kerja atau pendukung } \\
\text { ditempat kerja } \\
\text { kenyamanan }\end{array}$ & 2 & 1 & 8 & 6 & 3 & 53 \\
\hline 6 & Tersedia angkutan kerja untuk saya & - & - & 6 & 6 & 8 & 38 \\
\hline 7 & $\begin{array}{l}\text { Saya menjalin interaksi yang baik } \\
\text { dengan rekan kerja }\end{array}$ & 2 & 3 & 11 & 4 & 1 & 64 \\
\hline 8 & $\begin{array}{l}\text { Hubungan atasan dan bawahan } \\
\text { berlangsung baik }\end{array}$ & 3 & 2 & 9 & 4 & 2 & 60 \\
\hline 9 & $\begin{array}{l}\text { Saya dan rekan kerja saya saling } \\
\text { membantu dalam menyelesaikan } \\
\text { pekerjaan }\end{array}$ & 1 & 3 & 8 & 5 & 4 & 55 \\
\hline 10 & $\begin{array}{l}\text { Saya akan membantu rekan kerja } \\
\text { yang mengalami kesulitan dalam } \\
\text { pekerjaan }\end{array}$ & 3 & 3 & 7 & 5 & 2 & 60 \\
\hline & Jumlah Total & & & & & & 570 \\
\hline
\end{tabular}

Ket : SS= Sangat Setuju; S=Setuju; KS=Kurang Setuju;TS=Tidak Setuju; STS=Sangat Tidak Setuju Sumber: Hasil pengolahan data penelitian (2021)

Berdasarkan Tabel 3, dapat diketahui dari kuesioner pra survei mengenai lingkungan kerja pada UMKM Pengrajin Sepatu di Wilayah Gunung Puntang 
belum cukup optimal, hal ini dapat dilihat dari nilai skor yang terendah yaitu 38 mengenai angkutan kerja, sedangkan untuk nilai tertinggi dengan skor 64 mengenai hubungan rekan kerja setingkat, dari semua pernyataan yang diajukan diperoleh total skor yaitu 570 maka dapat diinterpretasikan bahwa kondisi lingkungan kerja kurang baik.

Berdasarkan latar belakang tersebut, maka peneliti tertarik untuk membuat suatu pokok bahasan penelitian dengan judul "Pengaruh Beban Kerja, Disiplin Kerja, dan Lingkungan Kerja Terhadap Produktivitas Kerja Karyawan (Studi Pada UMKM Pengrajin Sepatu Di Wilayah Gunung Puntang)”.

\section{METODOLOGI}

\section{Metode Analisis}

Metode yang digunakan dalam penelitian ini adalah metode kuantitatif dengan pendekatan deskriptif verifikatif dan teknik pengumpulan data dilakukan dengan metode survei. Definisi metode analisis deskriptif menurut Sugiyono (2017) adalah penelitian yang dilakukan untuk mengetahui keberadaan variabel mandiri, baik hanya pada satu variabel atau lebih (variabel yang berdiri sendiri) tanpa membuat perbandingan dan mencari hubungan variabel itu dengan variabel yang lain.

Metode verifikatif menurut Sugiyono (2017) adalah penelitian yang dilakukan terhadap populasi atau sampel tertentu dengan tujuan untuk menguji hipotesis yang telah ditetapkan. Dalam penelitian ini penulis menggunakan metode penelitian kuantitatif dengan pendekatan deskriptif dan verifikatif. Penelitian ini menggunakan pendekatan deskriptif akan digunakan untuk mendeskripsikan permasalahan yang berkaitan dengan Pengaruh Beban Kerja, Disiplin Kerja dan Lingkungan Kerja Terhadap Produktivitas Kerja Karyawan (Studi Pada UMKM Pengrajin Sepatu Di Wilayah Gunung Puntang). Pendekatan verifikatif bertujuan untuk menjawab seberapa besar pengaruh Beban Kerja, Disiplin Kerja, dan Lingkungan Kerja Terhadap Produktivitas Kerja Karyawan Karyawan (Studi Pada UMKM Pengrajin Sepatu Di Wilayah Gunung Puntang).

\section{Operasionalisasi Variabel Penelitian}

Variabel yang digunakan dalam penelitian ini adalah:

\section{Variabel Dependen (Y)}

Menurut Sugiyono (2017), variabel terikat merupakan variabel yang dipengaruhi atau yang menjadi akibat, karena adanya variabel bebas. Adapun Variabel terikat atau variabel dependen pada penelitian ini adalah produktivitas kerja yaitu sebagai variabel $Y$ skala atau ukuran yang digunakan dalam penelitian ini adalah ordinal.

\section{Variabel Independen $\left(X_{1}, X_{2}, X_{3}\right)$}

Menurut Sugiyono (2017), variabel bebas adalah variabel memengaruhi atau yang menjadi sebab perubahannya atau timbulnya variabel dependen 
(terikat). Variabel bebas dalam penelitian ini adalah Beban Kerja $\left(\mathrm{X}_{1}\right)$, Disiplin kerja $\left(\mathrm{X}_{2}\right)$, Lingkungan kerja $\left(\mathrm{X}_{3}\right)$.

\section{Jenis Sumber Data}

Adapun jenis data yang digunakan berdasarkan sumbernya adalah sebagai berikut :

\section{Data primer}

Data primer yaitu data yang dikumpulkan dan diperoleh secara langsung dari responden dengan menggunakan angket atau kuisioner. Data primer dalam penelitian ini diperoleh dengan menyebarkan angket atau kuisioner kepada karyawan UMKM pengrajin sepatu di Wilayah Gunung Puntang.

\section{Data Sekunder}

Data sekunder yaitu data pendukung yang telah tersedia. Data diperoleh dari dokumen atau laporan yang tersedia pada UMKM sepatu di Wilayah Gunung Puntang yang berhubungan dengan lingkungan kerja, disiplin kerja dan produktivitas kerja karyawan.

\section{Teknik Pengumpulan Data}

Teknik pengumpulan data yang digunakan dalam penelitian ini adalah :

1. Wawancara (interview), yaitu cara pengumpulan data dengan melakukan tanya jawab secara langsung kepada beberapa orang yang berkaitan dengan penelitian, yaitu karyawan pada UMKM pengrajin sepatu di Wilayah Gunung Puntang.

2. Angket atau kuesioner, yaitu teknik pengumpulan data dengan membuat daftar pertanyaan yang berkaitan dengan objek yaitu karyawan yang diteliti, diberikan kepada pimpinan atau pihak yang berwenang atau bagian lain yang berhubungan langsung dengan objek yang diteliti yaitu karyawan pada UMKM pembuatan sepatu di Wilayah Gunung Puntang.

3. Dokumentasi, yaitu pengumpulan data dari dokumen-dokumen yang ada pada perusahaan yang sedang di teliti yaitu pada UMKM pembuatan sepatu di Wilayah Gunung Puntang.

4. Studi Pustaka, yaitu dilakukan dengan cara mengumpulkan data yang relevan atau sesuai yang dibutuhkan untuk penelitian dari buku, artikel ilmiah, berita, maupun sumber kredibel lainnya yang reliabel dan juga sesuai dengan topik penelitian yang dilakukan.

\section{Teknik Penarikan Sampel}

Menurut Sugiyono (2013), populasi adalah wilayah generalisasi yang terdiri dari objek dan subjek yang mempunyai kuantitas dan karakteristik tertentu yang diterapkan oleh peneliti untuk dipelajari dan kemudian ditarik kesimpulan. Populasi dalam penelitian ini adalah seluruh karyawan UMKM pengrajin sepatu yang berjumlah 102 orang. Adapun penentuan jumlah sampel dalam penelitian 
ini adalah dengan menggunakan Teknik Slovin. Menurut Husein (2013), Rumus Slovin untuk menentukan sampel adalah sebagai berikut:

$$
n=\frac{N}{1+N(e)^{2}}
$$

Keterangan :

$\mathrm{n}$ = Ukuran Sampel

$\mathrm{N}=$ Ukuran Populasi

$\mathrm{e}=$ Batas toleransi kesalahan

Pengambilan sampel dalam penelitian ini dilakukan pada tingkat kepercayaan 90 persen atau nilai kritis sebesar 10 persen sehingga ukuran sampel dapat dihitung sebagai berikut :

$$
\begin{aligned}
& n=102 /\left(1+102(10 \%)^{2}\right. \\
& S=50,4
\end{aligned}
$$

Berdasarkan hitungan tersebut, maka sampel yang diambil sebanyak 50,4 atau dibulatkan menjadi 51 .

\section{Teknik Analisis Data dan Pengujian Hipotesis Analisis Deskriptif}

Analisis deskriptif digunakan untuk menjawab rumusan masalah pertama, kedua, ketiga dan keempat terkait dengan Beban Kerja $\left(\mathrm{X}_{1}\right)$, Disiplin Kerja $\left(\mathrm{X}_{2}\right)$, lingkungan Kerja $\left(\mathrm{X}_{3}\right)$, dan Produktivitas Kerja $(\mathrm{Y})$ karyawan (Studi Pada UMKM Pembuatan Sepatu Di Wilayah Gunung Puntang) dengan menggunakan tabel frekuensi.

\section{Analisis Verifikatif}

Analisis verifikatif menurut Sugiyono (2017) adalah metode penelitian melalui pembuktian untuk menguji hipotesis hasil penelitian deskriptif dengan perhitungan statistika sehingga didapat hasil pembuktian yang menunjukkan hipotesis ditolak atau diterima. Dalam penelitian ini analisis verifikatif bermaksud untuk menentukan seberapa kuatnya pengaruh variabel bebas yaitu Beban Kerja, Disiplin Kerja $\left(\mathrm{X}_{2}\right)$, lingkungan Kerja $\left(\mathrm{X}_{1}\right)$ dan Produktivitas Kerja $(\mathrm{Y})$ karyawan pada UMKM Pembuatan Sepatu Di Wilayah Gunung Puntang.

\section{Persamaan Regresi Linier Berganda:}

$$
Y=\alpha+\beta_{1} X_{1}+\beta_{2} X_{2}+\beta_{3} X_{3}+e
$$

\section{Keterangan:}

$\mathrm{Y} \quad=$ Produktivitas Kerja

a $\quad=$ Konstanta

$\beta \quad=$ Koefisien Regresi 


$$
\begin{array}{ll}
\mathrm{X}_{1} & =\text { Beban Kerja } \\
\mathrm{X}_{2} & =\text { Disiplin Kerja } \\
\mathrm{X}_{3} & =\text { Lingkungan Kerja } \\
\mathrm{e} & =\text { Error (kesalahan) }
\end{array}
$$

\section{HASIL DAN PEMBAHASAN}

\section{Analisis Deskriptif Produktivitas Kerja Karyawan UMKM Pengrajin Sepatu di Wilayah Gunung Puntang}

Berdasarkan hasil penelitian bahwa produktivitas kerja secara keseluruhan masuk ke dalam kategori baik. Dari hasil perhitungan menunjukkan total skor 2384 berada pada interval Baik (2080,8-2570,4). Maka dapat disimpulkan bahwa produktivitas kerja karyawan UMKM Pengrajin Sepatu di Wilayah Gunung Puntang adalah baik. Hal ini sejalan dengan penelitian Riskayani (2021) dalam penelitiannya yang berjudul yang menyebutkan bahwa produktivitas memiliki total skor pada interval baik.

\section{Analisis Deskriptif Beban Kerja Karyawan UMKM Pengrajin Sepatu di Wilayah Gunung Puntang}

Berdasarkan hasil penelitian bahwa Beban Kerja secara keseluruhan masuk ke dalam kategori baik. Dari hasil perhitungan menunjukkan total skor 1472 berada pada interval baik (1213,8-1499,3). Maka dapat disimpulkan bahwa beban kerja karyawan UMKM Pengrajin Sepatu di Wilayah Gunung Puntang adalah baik. Hasil ini sejalan dengan penelitian Musa (2020) yang menyebutkan bahwa variabel Beban kerja berada pada interval baik.

\section{Analisis Deskriptif Disiplin Kerja Karyawan UMKM Pengrajin Sepatu di Wilayah Gunung Puntang}

Berdasarkan hasil penelitian bahwa Disiplin Kerja secara keseluruhan masuk ke dalam kategori baik. Dari hasil perhitungan menunjukkan total skor 1477 berada pada interval kurang baik (1193,4-1560,5). Maka dapat disimpulkan bahwa disiplin kerja karyawan UMKM Pengrajin Sepatu di Wilayah Gunung Puntang adalah baik. Hal ini sejalan dengan penelitian yang dilakukan Talakua dkk (2020) yang menyebutkan bahwa variabel Disiplin Kerja berada pada interval baik.

\section{Analisis Deskriptif Lingkungan Kerja Karyawan UMKM Pengrajin Sepatu di Wilayah Gunung Puntang}

Berdasarkan hasil penelitian bahwa lingkungan kerja secara keseluruhan masuk ke dalam kategori kurang baik. Dari hasil perhitungan menunjukkan total skor 1727 berada pada interval kurang baik (1326-1733). Maka dapat disimpulkan bahwa lingkungan kerja karyawan UMKM Pengrajin Sepatu di Wilayah Gunung Puntang adalah kurang baik. Hal ini sejalan dengan penelitian yang dilakukan 
oleh Fatmawati dkk (2020), yang menyebutkan bahwa kondisi lingkungan kerja karyawan berada pada interval kurang baik.

\section{Analisis Verifikatif}

Analisis regresi linier berganda bertujuan untuk mengetahui apakah ada pengaruh beban kerja, disiplin kerja dan lingkungan kerja terhadap produktivitas kerja karyawan. Berikut ini merupakan hasil regresi linier berganda dengan pengolahan data SPSS 21 ditunjukkan pada Tabel 5.

Tabel 5. Hasil Analisis Regresi Linear Berganda

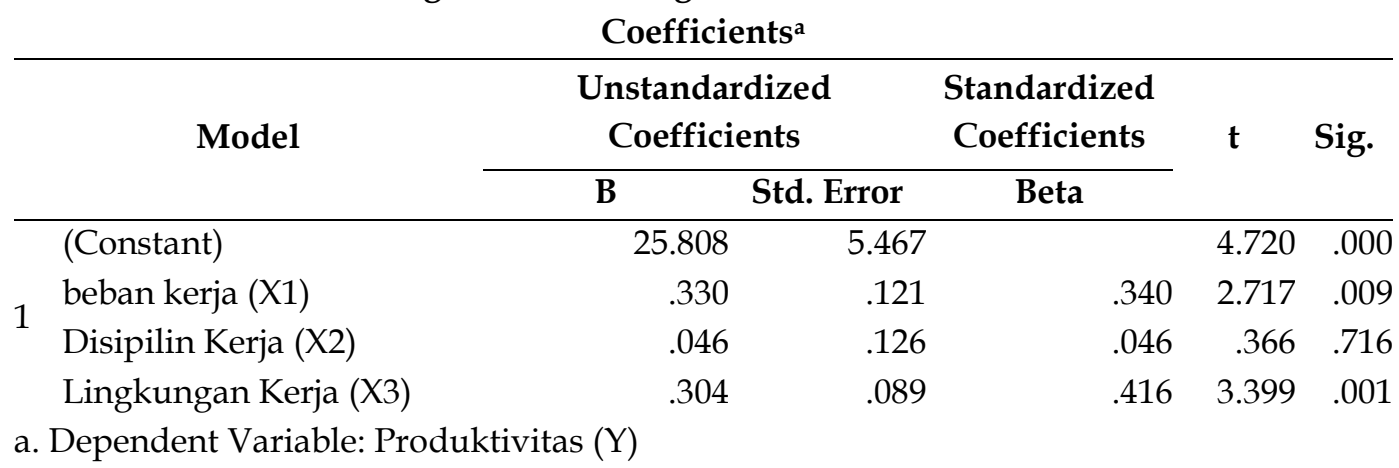

Sumber: Data Output SPSS 21 (2021), diolah

Berdasarkan Tabel 5, maka dapat diperoleh model persamaan regresi linier berganda sebagai berikut:

$$
\mathrm{Y}=25,808+0,330 \mathrm{X}_{1}+0,046 \mathrm{X}_{2}+0,304 \mathrm{X}_{3}
$$

Persamaan regresi linear berganda tersebut mempunyai arti bahwa :

1. Jika $\mathrm{a}=$ konstanta sebesar 25,808 dapat diartikan bahwa besarnya produktivitas karyawan akan naik sebesar 25,808 dengan asumsi beban kerja, disiplin kerja dan lingkungan kerja tidak mengalami perubahan (konstan).

2. Beban kerja mempunyai koefisien regresi dengan arah positif terhadap produktivitas kerja sebesar 0,330. Hal ini dapat diartikan bahwa pengaruh beban kerja searah dengan produktivitas kerja, yaitu setiap adanya kenaikan beban kerja maka akan terjadi kenaikan pada produktivitas kerja sebesar 0,330.

3. Disiplin kerja mempunyai koefisien regresi dengan arah positif terhadap produktivitas kerja sebesar 0,046. Hal ini dapat diartikan bahwa pengaruh Disiplin kerja searah dengan produktivitas kerja, yaitu setiap adanya peningkatan disiplin kerja maka akan terjadi peningkatan pada produktivitas kerja sebesar 0,046.

4. Lingkungan kerja mempunyai koefisien regresi dengan arah positif terhadap produktivitas kerja sebesar 0,304. Hal ini dapat diartikan bahwa pengaruh lingkungan kerja searah dengan produktivitas kerja, yaitu 
apabila terjadi kenaikan lingkungan kerja maka terjadi kenaikan pada produktivitas sebesar 0,304 .

\section{Analisis Koefisien Korelasi}

Berikut ini hasil pengujian koefisien korelasi dengan SPSS versi 21 yang dapat dilihat pada Tabel 6 .

Tabel 6. Hasil Analisis Koefisien Korelasi Berganda

\begin{tabular}{ccccccr}
\hline \multicolumn{6}{c}{ Model Summary $^{\mathrm{b}}$} \\
\hline Model & $\mathbf{R}$ & R Square & $\begin{array}{c}\text { Adjusted R } \\
\text { Square }\end{array}$ & $\begin{array}{c}\text { Std. Error of the } \\
\text { Estimate }\end{array}$ & Durbin-Watson \\
\hline 1 & $.550^{\mathrm{a}}$ & .303 & & .258 & 3.587 & 1.094 \\
\hline
\end{tabular}

a. Predictors: (Constant), Lingkungan Kerja (X3), beban kerja (X1), Disipilin Kerja (X2)

b. Dependent Variable: Produktivitas (Y)

Sumber: Data Output SPSS 21 (2021), diolah

Berdasarkan Tabel 6, maka didapat nilai korelasi untuk Beban Kerja, Disiplin Kerja dan Lingkungan Kerja dengan Produktivitas Kerja Karyawan adalah 0,550, artinya hubungan atau korelasi variabel Beban Kerja, Disiplin Kerja dan Lingkungan Kerja dengan Produktivitas Kerja Karyawan adalah sedang (berdasarkan tabel interpretasi koefisien korelasi berada pada interval 0,40-0,599). Hal ini sejalan dengan penelitian yang dilakukan oleh Asita (2017) yang menyebutkan bahwa, variabel Beban Kerja, Disiplin Kerja dan Lingkungan Kerja memiliki korelasi positif terhadap Produktivitas Kerja Karyawan.

\section{Analisis Koefisien Determinasi}

Berikut hasil analaisis koefisien determinasi dapat dilihat pada Tabel 7.

Tabel 7. Hasil Analisis Koefisien Determinasi

\begin{tabular}{ccccccr}
\multicolumn{8}{c}{ Model Summary $^{\mathrm{b}}$} \\
\hline Model & R & R Square & $\begin{array}{c}\text { Adjusted R } \\
\text { Square }\end{array}$ & $\begin{array}{c}\text { Std. Error of the } \\
\text { Estimate }\end{array}$ & Durbin-Watson \\
\hline 1 & $.550^{\mathrm{a}}$ & .303 & & .258 & 3.587 & 1.094
\end{tabular}

a. Predictors: (Constant), Lingkungan Kerja (X3), beban kerja (X1), Disipilin Kerja (X2)

b. Dependent Variable: Produktivitas (Y)

Sumber: Data Output SPSS 21 (2021), diolah

Berdasarkan Tabel 7, dapat diperoleh koefisien determinasi R-square sebesar 0,303. Nilai R-square menunjukkan ada Koefisien Determinasi, jadi nilai koefisien determinasi $(\mathrm{Kd})=0,303$ (30,3 persen). Hal ini berarti Produktivitas Kerja Karyawan dipengaruhi oleh Beban Kerja, Disiplin Kerja dan Lingkungan Kerja sebesar 30,30 persen sedangkan sisanya 69,70 persen dipengaruhi oleh faktor lain. Hal ini sejalan dengan penelitian Asita (2017) yang menyebutkan bahwa variabel Beban Kerja, Disiplin Kerja dan Lingkungan Kerja berpengaruh terhadap Produktivitas Kerja. 


\section{Uji Hipotesis}

\section{Pengujian Hipotesis Secara Parsial (Uji t)}

Uji hipotesis dilakukan dengan menggunakan uji statistik $t$ yang bertujuan untuk mengetahui apakah terdapat pengaruh Beban Kerja, Disiplin Kerja dan Lingkungan Kerja secara parsial terhadap Produktivitas Kerja Karyawan. Berikut hasil uji t dengan menggunakan SPSS 21 dapat dilihat pada Tabel 8.

Tabel 8. Hasil Uji t (Parsial) Penelitian

\begin{tabular}{|c|c|c|c|c|c|}
\hline \multicolumn{6}{|c|}{ Coefficients $^{a}$} \\
\hline \multirow[b]{2}{*}{ Model } & \multicolumn{2}{|c|}{$\begin{array}{l}\text { Unstandardized } \\
\text { Coefficients }\end{array}$} & \multirow{2}{*}{$\begin{array}{c}\begin{array}{c}\text { Standardized } \\
\text { Coefficients }\end{array} \\
\text { Beta }\end{array}$} & \multirow[b]{2}{*}{$\mathbf{t}$} & \multirow[b]{2}{*}{ Sig. } \\
\hline & B & Std. Error & & & \\
\hline (Constant) & 25.808 & 5.467 & & 4.720 & .000 \\
\hline Beban Kerja $\left(X_{1}\right)$ & .330 & .121 & .340 & 2.717 & $.00 s$ \\
\hline Disipilin Kerja $\left(X_{2}\right)$ & .046 & .126 & .046 & .366 & .716 \\
\hline Lingkungan Kerja $\left(X_{3}\right)$ & .304 & .089 & .416 & 3.399 & .001 \\
\hline a. Dependent Variable: $\operatorname{Pr}$ & ktivitas & & & & \\
\hline
\end{tabular}

Sumber: Data Output SPSS 21 (2021), diolah

1. Nilai signifikansi Beban Kerja terhadap Produktivitas Kerja adalah sebesar 0,009 lebih kecil dari 0,05 $(0,009<0,05)$ maka dapat disimpulkan bahwa $\mathrm{H}_{0}$ ditolak $\mathrm{H}_{\mathrm{a}}$ diterima, artinya secara parsial Beban Kerja berpengaruh signifikan terhadap Produktivitas Kerja.

2. Nilai signifikasnsi Disiplin Kerja terhadap Produktivitas Kerja adalah sebesar 0,716 lebih besar dari 0,05 $(0,716>0,05)$ maka dapat disimpulkan bahwa $\mathrm{H}_{0}$ diterima dan $\mathrm{H}_{\mathrm{a}}$ ditolak artinya secara parsial Disiplin Kerja tidak berpengaruh signifikan terhadap Produktivitas Kerja.

3. Nilai signifikasnsi Lingkungan Kerja terhadap Produktivitas Kerja adalah sebesar 0,001 lebih kecil dari 0,05 $(0,001<0,05)$ maka dapat disimpulkan bahwa $\mathrm{H}_{0}$ ditolak $\mathrm{H}_{\mathrm{a}}$ diterima, artinya secara parsial Lingkungan Kerja berpengaruh signifikan terhadap Produktivitas Kerja.

\section{Pengujian Hipotesis Secara Simultan (Uji F)}

Hasil uji hipotesis secara simultan (Uji F) dapat terlihat pada Tabel 9.

Tabel 9. Hasil Uji Secara Simultan (Uji F)

\begin{tabular}{rlrrrrr}
\multicolumn{7}{c}{ ANOVA $^{\mathbf{a}}$} \\
\hline Model & Sum of Squares & df & Mean Square & F & Sig. \\
\hline 1 & Regression & 262.895 & 3 & 87.632 & 6.810 & $.001^{\text {b }}$ \\
Residual & 604.791 & 47 & 12.868 & & \\
Total & 867.686 & 50 & & & \\
\hline
\end{tabular}

a. Dependent Variable: Produktivitas (Y)

b. Predictors: (Constant), Lingkungan Kerja (X3), beban kerja (X1), Disipilin Kerja (X2)

Sumber: Data Output SPSS 21 (2021), diolah 
Berdasarkan tabel 9, terlihat nilai sig. pada Beban Kerja $\left(\mathrm{X}_{1}\right)$, Disiplin Kerja $\left(X_{2}\right)$, dan Lingkungan Kerja $\left(X_{3}\right)$ adalah 0,001 Nilai sig. lebih kecil dari nilai probabilitas 0,05 atau nilai $0,001<0,05$ artinya bahwa secara simultan, variabel Beban Kerja $\left(X_{1}\right)$, Disiplin Kerja $\left(X_{2}\right)$, dan Lingkungan Kerja $\left(X_{3}\right)$ mempunyai pengaruh positif dan signifikan terhadap Produktivitas Kerja.

\section{KESIMPULAN DAN REKOMENDASI KEBIJAKAN}

Berdasarkan penelitian yang dilakukan maka didapatkan kesimpulan yaitu secara parsial, beban Kerja dan lingkungan kerja berpengaruh terhadap produktivitas kerja karyawan (studi pada UMKM Pengrajin Sepatu Di Wilayah Gunung Puntang). Sedangkan untuk variabel Disiplin Kerja tidak berpengaruh terhadap Produktivitas Kerja Karyawan. Variabel Beban Kerja, Disiplin Kerja dan Lingkungan Kerja secara bersama-sama (simultan) berpengaruh terhadap Produktivitas Kerja Karyawan. Dimana nilai R-square tersebut sebesar 0,303 (30,30 persen). Artinya semua variabel beban kerja, disiplin kerja dan lingkungan kerja memengaruhi produktivitas kerja sebesar 30,30 persen, sedangkan sisanya 69,70 persen dipengaruhi oleh faktor lain yang tidak di teliti.

Rekomendasi kebijakan yang disarankan untuk meningkatkan produktivitas kerja, hendaknya perusahaan juga meningkatkan lingkungan kerja dan disiplin kerja karyawan. Contohnya terkait dengan variabel Disiplin kerja, UMKM Pengrajin Sepatu di Wilayah Gunung Puntang perlu menerapkan sanksi jika melakukan pelanggaran terhadap aturan. Disisi lingkungan kerja, hendaknya perusahaan memperhatikan sarana dan prasarana yang mendukung lingkungan kerja agar para karyawan dapat merasa nyaman dalam melakukan pekerjaannya sehingga meningkatkan produktivitas kerja.

\section{DAFTAR PUSTAKA}

Asita, Ariza. 2017. Analisis Pengaruh Beban Kerja, Disiplin Kerja, Dan Lingkungan Kerja Terhadap Produktivitas Kerja Karyawan PT. Rukun Bersama Sentosa Kediri. Simki-Economic Vol. 01 No. 01 Tahun 2017.

Desmonanda, Agustin Ana. 2016. Pengaruh Lingkungan Kerja Fisik Terhadap Produktivitas Kerja Karyawan Pada PT. Federal International Finance Cabang Samarinda. eJournal Administrasi Bisnis, 2016, 4(4): 1179-1193.

Efendi, A., \& Suyadi, B. 2018. Pengaruh Lingkungan Kerja dan Keterampilan Kerja Terhadap Produktivitas Kerja Karyawan Pada Pabrik Rokok Gagak Hitam Kecamatan Maesan Kabupaten Bondowoso. Jurnal Pendidikan Ekonomi, Vol. 2 No. 2 (2018).

Fatmawati,dkk. 2020. Kinerja Karyawan Ditinjau Dari Kepemimpinan, Lingkungan Kerja, Dan Disiplin Kerja Pada Showroom Muhari Motor 651 Karanganyar. Edunomika - Vol. 04, No. 01 (Februari 2020).

Husein Umar. 2013. Metode Penelitian untuk Skripsi dan Tesis. Jakarta: Rajawali 
Mangkunegara. 2017. Manajemen Sumber Daya Manusia Perusahaan. Bandung: Remaja Rosdakarya.

Munandar, S. Ashar. 2011. Stress dan Keselamatan Kerja, Psikologi Industri dan Organisasi. Jakarta : Universitas Indonesia.

Radito, Th A. Analisis Pengaruh Disiplin Kerja, Lingkungan Kerja, dan Jaminan Sosial Terhadap Produktivitas Kerja Pegawai. Jurnal Bisnis, Manajemen, dan Akuntansi, [S.1.], Vol. 3, No. 2, September 2016. ISSN 2252-5483

Riskayani, Eneng. 2021. Pengaruh Lingkungan Kerja Dan Disiplin Kerja Terhadap Produktivitas Kerja Karyawan (Studi Pada UMKM Pengrajin Sepatu Di Wilayah Gunung Puntang). Skripsi : Universitas Inaba.

Sedarmayanti. 2017. Manajemen Sumber Daya Manusia. Bandung: Refika Aditama.

Saleh, Abdul R. 2018. Pengaruh Disiplin Kerja, Motivsi Kerja, Etos Kerja dan Lingkunga Terhadap Produktivitas Kerja Karyawan Bagian Produksidi PT. Inko Java Semarang. Jurnal Among Makarti, Vol. 11 No.1 Tahun 2018.

Siagian. 2014. Manajemen Sumber Daya Manusia .Jakarta: Bumi Aksara.

Sugiyono. 2017. Metode Penelitian Kuantitatif, Kualitatif, dan R\&D. Bandung: CV Alfabeta.

Sumajouw, Elisa \& Dkk. 2018. Pengaruh Karakterisktik Pekerjaan,Lingkungan Kerja Terhadap Produktivitas Kerja Pegawai Dinas Pendidikan Daerah Provinsi Sulawesi Utara. Jurnal EMBA, Vol. 6 No. 4 (2018).

Suprapto, Ribut. 2016. Pengaruh Disiplin Kerja Dan Lingkungan Kerja Terhadap Produktivitas Kerjakaryawan Bank BRI Syariah Kantor Cabang Pembantu Genteng Banyuwangi. Jurnal Hukum Islam, Ekonomi Dan Bisnis, Vol. 2 No.2 (2016).

Susanto, Budi. 2016. Pengaruh Disiplin Dan Pembagian Kerja Terhadap Kinerja Karyawan Pada Koperasi TKMB Di Tanjung Redeb. STIE Muhamamadiyah Tanjung Redeb. Januari 2016, Tersedia, (www.stiemsamarinda.ac.id/soal/soal34.pdf.

Sutrisno, E. 2016. Manajemen Sumber Daya Manusia. Jakarts: Prenanadamedia Grup.

Talakua, Yani,dkk. 2020. Pengaruh Disiplin Kerja Terhadap Kinerja Karyawan Pada RSU Bhakti Rahayu Ambon .Jurnal Inovasi Penelitian Vol.1 No.7 Desember 2020.

Virginia, \& Genta, R. 2020. Pengaruh Motivasi Kerja, Lingkungan Kerja dan Upah Terhadap Produktivitas Kerja Karyawan PT Dayana Cipta. Jurnal EMBA, Vol. 8 No. 1(2020). 